\title{
Wzajemne relacje dziennikarstwa wojennego i stosunków międzynarodowych - przyczyny, mechanizmy, konsekwencje
}

Media, czyli przestrzeń informacyjna, w której relacjonowane są konflikty zbrojne, zarówno te o zasięgu regionalnym, jak i lokalnym, stanowią jednocześnie obszar, w którym przedstawiane są poglądy polityczne przywódców państw, ścierają się ze sobą rozmaite nurty ideologiczne, prezentowane są stanowiska rządów i grup społecznych. Celem artykułu jest próba uchwycenia obustronnych relacji między dziennikarstwem wojennym a stosunkami międzynarodowymi - próba odpowiedzi na pytania, dlaczego i w jaki sposób wpływają wzajemnie na siebie? Ponadto, jakie są tego konsekwencje zarówno dla środowiska międzynarodowego, jak i dla mediów? Analizą badawczą objęte zostały zjawiska medialne i polityczne, mające miejsce w historii i w czasach najnowszych.

Przytaczając jedną z najprostszych definicji pojęcia „stosunki międzynarodowe”, należy uznać, że są to: „stosunki społeczne, które kształtują się ponad granicami państw i dotyczą relacji między różnymi podmiotami życia międzynarodowego"1. Już same transnarodowe organizacje medialne, globalny przepływ informacji (np. Internet) czy międzynarodowe transmisje telewizyjne, kształtujące opinię publiczną w wielu krajach za pomocą tych samych przekazów i treści (również na temat trwających aktualnie konfliktów zbrojnych), dowodzą, że media są podmiotami,

* Dr, Uniwersytet Łódzki, Wydział Studiów Międzynarodowych i Politologicznych, Katedra Studiów Brytyjskich i Krajów Wspólnoty Brytyjskiej, e-mail: zbigniew.bednarek@uni.lodz.pl.

1 I. Wyciechowska, Stosunki międzynarodowe i ich uwarunkowania, [w:] Społeczeństwo i polityka. Podstawy nauk politycznych, red. K.A. Wojtaszczyk, W. Jakubowski, Aspra JR, Warszawa 2003, S. 583. 
uczestnikami stosunków międzynarodowych. Uściślając, ze względu na dziedzinę oddziaływań media funkcjonują w obszarze międzynarodowych stosunków społecznych, które z jednej strony charakteryzują się różnym stopniem autonomiczności wobec państwa, a z drugiej - są bezpośrednimi i pośrednimi oddziaływaniami, których przedmiotem są chociażby kultura (szeroko rozumiana) czy informacja ${ }^{2}$. $\mathrm{W}$ odniesieniu do roli, jaką odgrywają media w stosunkach międzynarodowych, należy wspomnieć o koncepcji soft power, którą stworzył Joseph Nye. Termin ten oznacza zdolność kraju do osiągania własnych celów w polityce międzynarodowej poprzez przekonywanie i przyciąganie w oparciu o atrakcyjność własnej kultury czy ideałów. Tym samym soft power jest przeciwstawna do koncepcji hard power, będącej umiejętnością wymuszenia przez kraj własnych celów w polityce międzynarodowej dzięki jego potędze gospodarczej lub militarnej ${ }^{3}$.

Wiadomości z frontu nadsyłane do redakcji na bieżąco i w miarę systematycznie w postaci newsów czy reportaże, publikacje wydawane w formie książkowej już po powrocie dziennikarza do kraju, tworzą (zarówno w polskiej, jak i światowej tradycji dziennikarskiej) bogaty zestaw tekstów, który klasyfikuje się pod całościową nazwą „korespondencja wojenna” - dla ścisłości należy dodać, że jest to:

odmiana gatunkowa tekstów dziennikarskich, których głównym tematem są aktualne wydarzenia związane z konfliktami zbrojnymi i rewolucjami, jakich korespondent jest uczestnikiem, świadkiem lub poznał je na miejscu z opowieści innych obserwatorów (ex visione lub ex audio $)^{4}$.

Co więcej, korespondencję wojenną uważam nie tylko za odmianę gatunkową tekstów dziennikarskich, ale z punktu widzenia genologii ze względu na jej złożoną, hybrydyczną strukturę uznaję, że jest ona metagatunkiem, stojącym ponad wieloma gatunkami, łączącym ich elementy. Jest to bowiem forma wypowiedzi mogąca być zlepkiem cech co najmniej czternastu innych gatunków dziennikarskich i ich odmian ${ }^{5}$. Tym samym dziennikarstwo wojenne przekracza nie tylko

2 W. Szymborski, Międzynarodowe stosunki polityczne, Wydawnictwo Edukacyjne WERS, Bydgoszcz 2012, s. 12.

3 J. Jr Nye, Soft Power: The Means to Success in World Politics, Public Affairs, New York 2004. Por. J. Jr Nye, The Future of Power, Public Affairs, New York 2011 oraz L. Roselle, A. Miskimmon, B. O'Loughlin, Strategic Narrative. A New Means to Understand Soft Power, "Media, War \& Conflict" 2014, nr 7(1), s. 70-84.

4 Szerzej na ten temat piszę w opracowanym przez siebie haśle korespondencja wojenna [w:] Stownik rodzajów i gatunków literackich. Nowe wydanie, red. G. Gazda, Wydawnictwo Naukowe PWN, Warszawa 2012, s. 484-488. Cytat pochodzi ze strony 484.

5 Szerzej na ten temat piszę w artykule pt. Kategorie genologiczne ortogatunku, paragatunku i metagatunku, „Acta Universitatis Lodziensis. Folia Litteraria Polonica” 2013, nr 20: Dziennikarstwo, red. B. Bogołębska, M. Woźniak-Łabieniec, s. 111-123. 
granice między państwami czy narodami, ale teksty, które są jego rezultatem, przekraczają również swoje granice gatunkowe.

W rozwoju najpierw informacji wojennej, a następnie dziennikarstwa wojennego można wskazać kilka punktów w czasie bardzo ważnych, wręcz przełomowych dla tej dyscypliny. Jeden z nich przypada na rok 1661, gdy ukazywała się najstarsza polska periodyczna gazeta „Merkuriusz Polski, dzieje wszystkiego świata w sobie zamykający dla informacji pospolitej" - Rzeczpospolita w latach 1654-1667 prowadziła wojnę $\mathrm{z}$ Rosją, a informacje o jej przebiegu zamieszczano właśnie w wydaniach tej gazety. Kolejny przełomowy okres to epoka napoleońska, gdyż do tego czasu nie uważano za celowe informowanie opinii publicznej o przebiegu konfliktów ${ }^{6}$, które relacjonowane były wyłącznie przez wojskowych dowódców lub żołnierzy, a ich przekazy spisywano $\mathrm{w}$ formie wojskowego raportu? ${ }^{7}$. Wartość informacyjna korespondencji wojennej została doceniona przez społeczeństwo właściwie dopiero za czasów Napoleona. To on zrozumiał wagę powiadamiania opinii publicznej o postępach wojsk ${ }^{8}$. Poinformowanie społeczeństwa o przebiegu wojny, a w szczególności o sukcesach odnoszonych przez armię może w efekcie przełożyć się na wzrost poparcia dla działań władzy.

Odwrotny skutek powodowały zdjęcia, które nadsyłał William Howard Russell z wojny krymskiej toczącej się w latach 1853-1856. Był on jednym z pierwszych fotografów wojennych, został wysłany na tę wojnę przez brytyjski magazyn „Times”. Henryk Latoś pisze o nim następująco:

Pisał on o cholerze dziesiątkującej szeregi armii brytyjskiej przybyłej w okolice Warny, o setkach rannych pozostających bez opieki na polach bitew, o fetorze i brudzie w zaniedbanych szpitalach polowych, o śmierci i zniszczeniach [...]. Na domiar złego dziennikarz ten ośmielał się zadawać pytania o sens wojny, o cele, które miała osiągnąć, i czy cena, jaką płacą prości żołnierze, nie jest zbyt wysoka.

Jak dalej pisze Latoś, takich relacji z pola walki ówczesna brytyjska opinia publiczna, której zdanie zaczęło się coraz bardziej liczyć, znieść nie mogła - nie była przyzwyczajona do tak drastycznych wiadomości. Angielskie społeczeństwo było wstrząśnięte, bo po raz pierwszy dowiedziało się, jak wojna wygląda naprawdę, a jego reak-

6 A. Osińska, Historiainformacji wojennej, http://www.reporterzy.info/article.php?go=historia,37,historia_informacji_wojennej [dostęp: 21.06.2008].

7 M. Wańkowicz, Wojna i pióro, Wydawnictwo Ministerstwa Obrony Narodowej, wyd. 3, Warszawa 1983, s. 182-184.

8 A. Osińska, dz. cyt.

9 H. Latoś, Z historii fotografii wojennej, Wydawnictwo Ministerstwa Obrony Narodowej, Warszawa 1985, s. 26. 
cja spowodowała, że rząd ponownie ocenił kwestie leczenia żołnierzy oraz doprowadziła do zaangażowania się w tę sprawę Florence Nightingale ${ }^{10}$, która

w czasie wojny krymskiej [...] zorganizowała od podstaw opiekę nad rannymi żołnierzami [...] zdołała dzięki swej energii i zaangażowaniu poprawić fatalny stan sanitarny brytyjskich szpitali polowych [...]. Później została ekspertem Armii Brytyjskiej ds. wojskowej służby pielęgniarskiej"1.

Należy również wspomnieć o dwóch wielkich zmianach, jakie zaszły w światowym dziennikarstwie wojennym, mających wpływ na stosunki międzynarodowe. Wojna w Wietnamie (prowadzona w latach 1957-1975) była pierwszą wojną, w której dziennikarze zaczęli rezygnować $\mathrm{z}$ noszenia żołnierskich mundurów, a w latach siedemdziesiątych XX wieku pracowali już w ubraniach cywilnych. Chodziło bowiem o zachowanie neutralności i nieidentyfikowanie się z żadną armią, stroną konfliktu, dzięki czemu reporterzy mieli możliwość swobodnego poruszania się po terenach, na których toczyły się walki, a tym samym mogli dotrzeć do większej liczby Wietnamczyków, łatwiej zyskać ich zaufanie i opisać ich tragedie. Konsekwencją tej zmiany były sprawozdania $\mathrm{z}$ wojny ukazujące cierpienie ludności, które wraz z nurtem Writing Vietnam i naciskiem opinii publicznej wymusiły na władzach USA wycofanie się wojsk amerykańskich z Wietnamu. Warto wskazać m.in. dziennikarza Davida Halberstama, który

[w] serii korespondencji z Wietnamu pisał o słabościach i korupcji wspieranego przez USA rządu południowowietnamskiego oraz o szerokim poparciu, jakim wśród wieśniaków cieszyła się komunistyczna partyzantka Vietkong. W 1963 r. prezydent John F. Kennedy osobiście naciskał na wydawcę „New York Timesa”, by ten odwołał Halberstama z Wietnamu. Gazeta się nie ugięła ${ }^{12}$.

Krzysztof Mroziewicz wspomina, że „teksty [Halberstama] o Wietnamie $\mathrm{w}$ «New York Timesie» doprowadziły do zakończenia tej wojny”'13.

10 "His dispatches were hugely significant; for the first time the public could read about the reality of warfare. Shocked and outraged, the public's backlash from his reports led the Government to re-evaluate the treatment of troops and led to Florence Nightingale's involvement in revolutionising battlefield treatment". Za: https://en.wikipedia.org/wiki/William_Howard_ Russell [dostęp: 15.03.2017].

11 Za: https://pl.wikipedia.org/wiki/Florence_Nightingale [dostęp: 15.03.2017].

12 M. Gadziński, David Halberstam nie żyje, http://wiadomosci.gazeta.pl/wiadomosci/1,114881,4086443. html [dostęp: 15.03.2017].

13 K. Mroziewicz, Korespondent, czyli jak opisać pełzający koniec świata, Wydawnictwo Zysk i S-ka, Poznań 2013, s. 40. 
Z wojny w Wietnamie wyciągnięto wnioski, które przyczyniły się do drugiej wielkiej zmiany, jaka zaszła w światowym dziennikarstwie wojennym, po to, by korespondenci wojenni nie mieli już tak wielkiego wpływu na kształtowanie zagranicznej polityki amerykańskiej, a tym samym, by nie oddziaływali na stosunki międzynarodowe. Wielką rolę w tym względzie odegrała obowiązująca podczas interwencji w Iraku w 2003 roku tzw. Patriot Act, czyli ustawa, która widocznie ograniczała swobodę dziennikarzy i mediów w opisywaniu przebiegu konfliktów zbrojnych, w które Stany Zjednoczone były zaangażowane, przez co prowadzenie przez reporterów we własnym zakresie śledztw $\mathrm{w}$ terenie było istotnie utrudnio$\mathrm{n}^{14}$. Przyczyna tego była następująca:

Nie chciano, by powtórzyła się sytuacja z czasów wojny wietnamskiej, gdy w USA i w innych krajach nadmiar telewizyjnych relacji z frontów i obrazów cierpienia cywilów sprzyjał powstawaniu silnych ruchów antywojennych. Nie chciano również, by - jak było to w przypadku pierwszej wojny w Zatoce (1991) - niesforne media dowiadywały się więcej i szybciej o pewnych wydarzeniach na froncie, niż dowiadywali się o tym dowodzący operacją ${ }^{15}$.

Podczas wspomnianej interwencji zbrojnej w Iraku w 2003 roku nastąpił w mediach amerykańskich gwałtowny rozwój „dziennikarstwa skoszarowanego” (embedded journalism). Polega ono na tym, że dziennikarze są przydzieleni do wojskowych w konkretnym oddziale, ale „[...] są dopuszczani tylko do tych informacji, które wojsko chce rozpowszechniać", a tym samym stają się dla armii narzędziem służącym do prowadzenia wojny informacyjnej ${ }^{16}$. Oficjalnie chodziło o zapewnienie bezpieczeństwa korespondentom na wojnie.

Czy śmierć dziennikarza wojennego może zmienić relacje międzynarodowe? Warto wspomnieć, że Krzysztof Mroziewicz przytacza następującą historię o prezydencie Nikaragui Anastasio Somozie Debayle’u i mediach w 1979 roku:

Gwardzista Somozy zastrzelił korespondenta ABS News Williama „Billa” Stewarta, który relacjonował walkę sandinistów z reżimem wojskowym. Scena została zarejestrowana przez jego operatora, Jacka Clarka. Kiedy obejrzał ją w telewizji prezydent Jimmy Carter, USA postanowiły zdjąć parasol ochronny znad Somozy. Dyktator został wkrótce obalony, a potem sam zginą ${ }^{17}$.

14 Z. Bauer, Dziennikarstwo wobec nowych mediów. Historia, teoria, praktyka, Universitas, Kraków 2009, s. 236.

15 Tamże.

16 Za: A. Antczak, Korespondenci wojenni i oficerowie prasowi - współdziałanie czy przymus, „Studia Medioznawcze" 2010, nr 1, s. 65-77. Por. B. Katovsky, T. Carlson, Embedded: the media at war in Iraq, The Lyons Press, Guilfard 2003.

17 K. Mroziewicz, dz. cyt., s. 51. 
Kiedy w 2004 roku włoski dziennikarz Enzo Baldoni został porwany w Iraku, a jego porywacze wystosowali ultimatum wobec ówczesnego premiera Włoch Silvia Berlusconiego, żądając wycofania wojsk włoskich z Iraku, porwanie korespondenta nie wpłynęło na zmianę dotychczasowej polityki. Jak pisze Magdalena Hodalska,

śmierć Enzo Baldoniego była komunikatem wysłanym do polityków i opinii publicznej. Miała przede wszystkim przerazić przyszłych wyborców. Ta strategia terrorystów sprawdziła się już wcześniej: po marcowym zamachu w Madrycie proamerykański rząd Aznara upadł i wycofano wojska z Iraku' ${ }^{18}$.

W jaki sposób przekazy medialne kształtują obraz rzeczywistości, wpływając na stosunki międzynarodowe? Co jeszcze komunikują oprócz samego przekazania informacji? Jakich intencji nadawcy można się w nich dopatrywać? Jednym z mechanizmów jest - jak twierdzi Michael Ignatieff - „tworzenie i narzucanie adekwatnych narracji”, które „zmieniają historię w opowieść o dobrych i złych”"19. Wówczas opinia publiczna przyjmuje bardzo przejrzystą perspektywę konfliktu - tak było chociażby w kontekście wojny w Bośni i Hercegowinie (1992-1995), kiedy to w Stanach Zjednoczonych i państwach zachodniej Europy w sposób jednoznaczny za pozytywnych bohaterów walk (tzw. good guys) uznawano Bośniaków i Chorwatów, a za negatywnych (tzw. bad guys) - Serbów. W okresie tym widoczna jest działalność agencji lobbingowych i firm zajmujących się public relations, które nie tylko kształtowały medialny wizerunek wojen na Bałkanach, poglądy światowych polityków i opinie poszczególnych społeczeństw, ale - co więcej - stymulowały działania wielu rządów i instytucji międzynarodowych, które były „odpowiedzią na zapotrzebowanie społeczne, wytworzone na podstawie treści (i obrazów) przekazywanych przez media"20. Innym mechanizmem, za pomocą którego można wpływać na kształtowanie się relacji między państwami i narodami, jest już samo stosowanie w mediach, podejmujących temat konfliktów zbrojnych, konkretnych wyrażeń określających, za pomocą których można w bardzo prosty sposób kształtować poglądy odbiorców i pozyskiwać ich poparcie lub wywoływać negatywną reakcję. W literaturze zwraca się uwagę na to, że na początku 1998 albańska Armia Wyzwolenia Kosowa (UÇK) oceniana była przez USA jako „organizacja terrorystyczna”, a po kilku miesiącach jej członkowie byli nazywani przez zachodnie media "partyzantami” i „bojownikami”,

18 M. Hodalska, Korespondent wojenny: ofiarnik i ofiara we współczesnym świecie, Wydawnictwo UJ, Kraków 2006, s. 118.

19 M. Poletyło, Propaganda wojenna w liberalnej demokracji. Argument bałkański - analiza przypadku, Wydawnictwo Adam Marszałek, Toruń 2008, s. 6.

20 Tamże, s. 94. 
w czym upatrywano przejawu celowej polityki medialnej i gospodarczej Stanów Zjednoczonych ${ }^{21}$.

Łukasz S. Tomicki określił role, jakie mogą pełnić korespondenci wojenni za pośrednictwem swych publikacji; mogą oni ${ }^{22}$ :

- wpłynąć na obalenie władzy: „[...] William Howard Russell wiadomościami z wojny krymskiej wpłynął na obalenie gabinetu Aberdeena";

- wpłynąć na przejęcie władzy: „[...] William Howard Russell korespondencjami z buntu sipajów przyczynił się do zakończenia administracji East India Company i przejęcia władzy przez rząd";

- spowodować rozpoczęcie nowego konfliktu zbrojnego;

- przyczynić się do zaangażowania w trwającą wojnę nowych graczy politycznych: „,...] Mac Gahan korespondencjami z wojny bułgarsko-tureckiej przyczynił się do wybuchu wojny rosyjsko-tureckiej w 1878 roku; «Hearst» wraz $\mathrm{z}$ zespołem swoich korespondentów wpędzili Stany Zjednoczone w wojnę z Hiszpanią";

- spowodować utworzenie organizacji międzynarodowej: „[... [ korespondencja Russella z wojny krymskiej, wzbudzając sentymentalne uczucia wśród opinii publicznej, spowodowała utworzenie Czerwonego Krzyża; w związku z niebezpieczeństwem wynikającym z pracy korespondentów wojennych powstał Komitet Ochrony Dziennikarzy (Committe to Protect Journalists)";

- spowodować napięcia wewnętrzne: „[...] konsekwencją korespondencji z wojny francusko-niemieckiej z 1870 roku było powstanie komunardów";

- wpłynąć na wynik wojny „[...] przez informowanie lub zatajanie wiadomości stron o składzie i liczbie armii, jej rozlokowaniu, uzbrojeniu czy morale żołnierzy";

- wpłynąć na międzynarodowy system prawny: „[...] Declaration on the Protection of Journalists In Situation of Conflict and Tension - deklaracja utworzona przez Radę Europy";

- umożliwić proces secesji lub utworzenia nowego bytu prawno-międzynarodowego: „[...] bostońska herbata, która jako inscenizowana scena rozbudziła uwagę publiczną na problem zależności mieszkańców północnoamerykańskich kolonii od Wielkiej Brytanii”;

21 W pracy tej jedynie sygnalizuję te kwestie, gdyż szeroko ten temat traktuje mój inny artykuł: Z. Bednarek, Narracje wojenne i obrazy konfliktów kulturowo-politycznych: istota funkcjonowania w mediach a wpływ na postawy społeczeństw, [w:] Autopromocja, autoprezentacja, wizerunek w mediach masowych. Teoria i praktyka, red. A. Kalisz, E. Tyc, Wydawnictwo UŚ, Katowice 2017, s. 27-34.

22 Cytowane dalej egzemplifikacje za: Ł.S. Tomicki, Rola publicystyki wojennej w kształtowaniu opinii społecznej i międzynarodowej, http://www.racjonalista.pl/kk.php/s,5688 [dostęp: 15.06.2008]. 
- uzyskać poparcie dla działań militarnych;

- wywołać sprzeciw wobec działań militarnych;

- wywołać dezinformację przeciwnika „[...] przez świadome wprowadzenie w błąd przy pomocy komunikowania paradoksalnego, np.: akcja przeprowadzana przez aliantów podczas II wojny światowej, której celem było wprowadzenie Niemców w błąd co do lądowania desantu. Zastosowano przedstawienie prawdy jako fałszu";

- kształtować opinię publiczną „[...] w celu wywołania uczuć patriotycznych i romantycznych wobec własnych wojsk i piętnować oraz wywoływać nienawiść do przeciwników, przedstawiając ich negatywnie jako złą stronę konfliktu";

- wpłynąć na zmianę systemu politycznego: „[...] wolność prasy jest jednym z warunków funkcjonowania systemu demokratycznego. Na liście krajów, gdzie wolność ta jest na fatalnym poziomie są: Irak, Kuba, Czeczenia, Inguszetia, Turkmenistan, Bangladesz, Chiny, Erytrea, Haiti, Strefa Gazy i Zachodni Brzeg Jordanu".

Reporterzy wojenni, tworzący swoje teksty w tej wysoce specjalistycznej odmianie dziennikarstwa, konstruują dokumenty będące zapisem ważnych wydarzeń. Przekazując społeczeństwom informacje o sprawach polityki międzynarodowej, sami są uczestnikami stosunków międzynarodowych, kreatorami narracji medialnych i silnie oddziałują na opinię publiczną. W efekcie ich pracy możliwe staje się zwrócenie uwagi odbiorców na nieznane im wcześniej obrazy rzeczywistości, powstanie społecznych nacisków na władzę. Z drugiej jednak strony, przywódcy czy to wojskowi, czy polityczni wpływają na ich pracę, niekiedy wręcz ją ograniczając. Ponadto agencje lobbingowe i firmy zajmujące się public relations odgrywają niemałą rolę we wzajemnych relacjach dziennikarstwa wojennego i stosunków międzynarodowych. Relacje te - jak dowodzi powyższa analiza - są zmienne $\mathrm{w}$ czasie, ponieważ różne są interesy poszczególnych grup, a zatem na przestrzeni dziesięcioleci odmienne są przyczyny wzajemnych wpływów dziennikarstwa wojennego i stosunków międzynarodowych, rozmaite mechanizmy kształtujące te obie sfery, a konsekwencje czasem mało zauważalne. 


\section{Bibliografia}

Antczak A., Korespondenci wojenni i oficerowie prasowi - współdziałanie czy przymus, „Studia Medioznawcze” 2010, nr 1, s. 65-77.

Bauer Z., Dziennikarstwo wobec nowych mediów. Historia, teoria, praktyka, Universitas, Kraków 2009.

Bednarek Z., Kategorie genologiczne ortogatunku, paragatunku i metagatunku, „Acta Universitatis Lodziensis. Folia Litteraria Polonica” 2013, nr 20: Dziennikarstwo, s. 111-123.

Bednarek Z., Korespondencja wojenna, [w:] Słownik rodzajów i gatunków literackich. Nowe wydanie, red. G. Gazda, Wydawnictwo Naukowe PWN, Warszawa 2012, s. 484-488.

Bednarek Z., Narracje wojenne i obrazy konfliktów kulturowo-politycznych: istota funkcjonowania w mediach a wpływ na postawy społeczeństw, [w:] Autopromocja, autoprezentacja, wizerunek $w$ mediach masowych. Teoria i praktyka, red. A. Kalisz, E. Tyc, Wydawnictwo UŚ, Katowice 2017, s. 27-34.

Hodalska M., Korespondent wojenny: ofiarnik i ofiara we współczesnym świecie, Wydawnictwo UJ, Kraków 2006.

Ignatieff M., Homage to Bosnia, New York Review of Books, Nowy Jork 1994.

Katovsky B., Carlson T., Embedded. The media at war in Iraq, The Lyons Press, Guilfard 2003.

Latoś H., Z historii fotografii wojennej, Wydawnictwo Ministerstwa Obrony Narodowej, Warszawa 1985.

Mroziewicz K., Korespondent, czyli jak opisać pełzający koniec świata, Wydawnictwo Zysk i S-ka, Poznań 2013.

Nye J.S. Jr, Soft Power. The Means to Success in World Politics, Public Affairs, New York 2004.

Nye J.S. Jr, The Future of Power, Public Affairs, New York 2011.

Poletyło M., Propaganda wojenna w liberalnej demokracji. Argument bałkański - analiza przypadku, Wydawnictwo Adam Marszałek, Toruń 2008.

Roselle L., Miskimmon A., O'Loughlin B., Strategic Narrative. A New Means to Understand Soft Power, "Media, War \& Conflict" 2014, nr 7(1), s. 70-84.

Szymborski W., Międzynarodowe stosunki polityczne, Wydawnictwo Edukacyjne WERS, Bydgoszcz 2012.

Wańkowicz M., Wojna i pióro, Wydawnictwo Ministerstwa Obrony Narodowej, wyd. 3, Warszawa 1983.

Wyciechowska I., Stosunki międzynarodowe i ich uwarunkowania, [w:] Społeczeństwo i polityka. Podstawy nauk politycznych, red. K.A. Wojtaszczyk, W. Jakubowski, Oficyna Wydawnicza ASPRA, Warszawa 2003, s. 579-586. 


\section{Netografia}

Gadziński M., David Halberstam nie żyje, http://wiadomosci.gazeta.pl/wiadomosci/1,114881,4086443.html [dostęp: 15.03.2017].

https://en.wikipedia.org/wiki/William_Howard_Russell [dostęp: 15.03.2017].

https://pl.wikipedia.org/wiki/Florence_Nightingale [dostęp: 15.03.2017].

Osińska A., Historia informacji wojennej, http://www.reporterzy.info/article. php?go=historia,37,historia_informacji_wojennej [dostęp: 21.06.2008].

Tomicki Ł.S., Rola publicystyki wojennej w kształtowaniu opinii społecznej i międzynarodowej, http://www.racjonalista.pl/kk.php/s,5688 [dostęp: 15.06.2008].

Zbigniew Bednarek

\section{Wzajemne relacje dziennikarstwa wojennego i stosunków międzynarodowych - przyczyny, mechanizmy, konsekwencje}

\section{Streszczenie}

Celem artykułu jest próba uchwycenia obustronnych relacji między dziennikarstwem wojennym a stosunkami międzynarodowymi - próba odpowiedzi na pytania, dlaczego i w jaki sposób wpływają wzajemnie na siebie? Ponadto, jakie są tego konsekwencje zarówno dla środowiska międzynarodowego, jak i dla mediów? Analizą badawczą objęte są zjawiska medialne i polityczne, mające miejsce w historii i w czasach najnowszych.

Słowa kluczowe: dziennikarstwo wojenne, informacja wojenna, fotografia wojenna, stosunki międzynarodowe, polityka międzynarodowa, konflikt zbrojny, wojna, media. 


\section{Bilateral relations between war journalism and international relations - causes, mechanisms, consequences}

Summary

The aim of this article is to try to identify the bilateral relations between war journalism and international relations - it is an attempt to answer the questions of why and how they affect one another. Also, what are the consequences for both the international environment and the media? The research explores media and political phenomena that have taken place in history and in recent times.

Keywords: war journalism, war information, war photography, international relations, international politics, military conflict, war, media. 